\title{
The case for specific performance as remedy for breach of athletes' contracts
}

\author{
Kenneth Mould \\ Department of Private Law, \\ University of the Free State \\ Bloemfontein \\ South Africa \\ E-mail: mouldkl@ufs.ac.za

\section{Steve Cornelius} \\ Department of Private Law, \\ University of Pretoria, \\ Pretoria 0002, \\ South Africa \\ E-mail: Steve.Cornelius@up.ac.za
}

\begin{abstract}
The purpose of this article is to suggest to South African courts that specific performance is the most adequate remedy for breach of athletes' contracts. The current viewpoint of South African courts as to whether specific performance is in fact the most adequate remedy for breach of athletes' contracts, will be compared with that of courts within the federal government system of the United States of America. The reason for choosing this jurisdiction is twofold: firstly, the US has a particularly rich history of disputes involving repudiation of athletes' contracts and which remedies courts preferred for this type of breach, and secondly, a number of reputable scholars of US sports law have suggested that US courts should consider ordering affirmative injunctions against repudiating athletes - despite the Lumley rule which is considered the primary indicator of the most adequate remedy for breach of athletes' contracts in US law.
\end{abstract}

Keywords: Athletes' contracts; Professional sport; Specific performance; Injunction; Sui generis; Contractual remedies; Lumley rule; South Africa; United States of America; Sports contract 
Biographical notes: Kenneth Mould is Senior Lecturer in the Department of Private Law at the University of the Free State and holds the degrees LL.B LL.M BA (Hons) (UFS) LL.D (Pret.). He is admitted as Attorney and Conveyancer of the High Court of South Africa.

Steve Cornelius is Professor in and Head of the Department of Private Law at the University of Pretoria and holds the degrees BIuris LLB (Unisa) LLD (Pret). He is admitted as Advocate of the High Court of South Africa. He is rated by the National Research Foundation as an internationally renowned researcher. He is a member of the Editorial Advisory Board of the International Sports Law Journal which is published by the TMC Asser Institute in The Hague, Netherlands and the National Rapporteur for the International Sports Law Review Pandektis, which is the official journal of the International Association of Sports Law.

\section{Introduction}

The purpose of this article is to suggest to South African courts that specific performance is the most adequate remedy for breach of athletes' contracts. To date, the Supreme Court of Appeal of South Africa ${ }^{1}$ has not had an opportunity to assess the most adequate remedy for breach of athletes' contracts. However, considering the vast amounts of money involved in the professional sporting industry of South Africa (not to even mention in Europe and the US), it should not take long for a matter concerning repudiation of a professional athlete's contract to reach the SCA. South African case law on the most adequate remedy for breach of athletes' contracts is limited. To date, the Full Bench of the Western Cape High Court's decision in Santos Professional Football Club (Pty) Ltd v Igesund and Another ${ }^{2}$ represents the most authoritative decision on the question of whether specific performance should be considered an adequate remedy for breach of athletes' contracts. There is little to criticize about this decision, but it should be kept in mind that the respondent was not a professional athlete but professional coach, and therefore does not fall squarely within the topic at hand. Furthermore, the court could have made more of the nature of the contract in question. The nature of athletes' contracts will be addressed in this article in order to show that special cognizance should be taken of the sui generis characteristics of athletes' contracts when deciding on the most adequate (and suitable) remedy for breach of athletes' contracts. 
The viewpoint currently adopted by South African courts as to whether specific performance is in fact the most adequate remedy for breach of athletes' contracts, will be compared with that of courts within the federal government system of the United States of America. ${ }^{3}$ The reason for choosing this jurisdiction is twofold: firstly, the US has a particularly rich history of disputes involving repudiation of athletes' contracts and which remedies courts preferred for this type of breach, and secondly, a number of reputable scholars of US sports law ${ }^{4}$ have suggested that US courts should consider ordering affirmative injunctions against repudiating athletes - despite the Lumley rule ${ }^{5}$ which is considered the primary indicator of the most adequate remedy for breach of athletes' contracts in US law. There are, therefore, vital lessons to be learned from US case law on the current topic. It is true that the majority of states within the US have vastly different common law rules relating to contractual remedies from South Africa with its Roman-Dutch roots. What makes this study viable, however (and makes the two jurisdictions comparable as far as the most adequate remedy is concerned) is the fact that the athlete's contract is a global legal tool whose nature transcends borders of different systems of common law.

\section{The nature of athletes' contracts}

\subsection{Background}

One cannot determine the most adequate remedy for breach of a specific type of contract such as the athlete's contract without a proper understanding of the nature thereof.

There is no doubt that US authorities consider the athlete's contract (in the guise of the Standard Players' Contract $^{6}$ ) as a sui generis legal tool. Rapp ${ }^{7}$ states that "the professional athletic career is different than other jobs..." At the core of this uniqueness lies the fact that players' contracts are negotiated on equal footing, with the parties possessing equal bargaining power. The Standard Player's Contract contains clauses to the effect that it is expected of the player in question to acknowledge contractually that he possesses exceptional knowledge, skill, ability and experience as a professional sportsman, the loss of which cannot be estimated with any certainty and cannot be fairly or adequately compensated by damages. ${ }^{8}$ In the Standard Players' Contract of the US, a player therefore actually agrees to injunctive relief in case he or she should commit breach of contract.

If one attempts to argue that South African courts should pay heed to US authorities as far as the most adequate remedy for breach of athletes' contracts is concerned, then one must first 
ascertain whether South African authorities perceive the athletes' contract as a sui generis legal tool resembling the Standard Players Contract.

\subsection{The nature of athletes' contracts as perceived by South African authorities}

It has been well-documented by several South African authorities ${ }^{9}$ that the relationship between professional athletes and their employers is one of employment, and therefore subject to statutes, rules and regulations pertaining to labour law. Louw ${ }^{10}$ lists the following characteristics of the "relationships of these people (professional athletes) to the unions or governing bodies to whom athletic or sporting services are rendered":

(i) 'The standard players' contracts all provide for an obligation on the part of the player to perform personal sporting services to the other party.

(ii) These athletic services are rendered subject to the control and direction of such other partyalthough the measure of such control may differ from that found with other employees, the inherent control is always present and especially evident in for instance the practice of selection of players for matches.

(iii) These agreements all provide for the absorption of the player's labour power in respect of the rendering of athletic services, either to the exclusion or semi-exclusion of other employers.

(iv) The remuneration payable as a reciprocal obligation in return for services rendered contains traditional elements found in the employment of other employees, e.g. medical aid and retirement contributions paid by the employer.

(v) These agreements provide for power on the part of the employer to discipline and dismiss players for misconduct or poor work performance, which in some cases exceed the measure of control (as found in "ordinary" employment contracts over the autonomy of the employee in respect of their physical integrity and the pursuit of outside or personal interests and activities).

(vi) The wording of the players' contracts in all these cases explicitly refer to the relationship as one of "employment", and to the parties as "employer" and "employee".

(vii) The relationship between the parties falls squarely within the legislative definition of employment, and such players are nowhere expressly excluded from the ambit of such legislation."

The characteristics listed by Louw above create the dominant impression that the contract between a professional athlete and his "employer" is one of employment. This is an 
oversimplification. It is essential to show that while there are certain characteristics of the athlete's contract that do correspond with those of the employment contract, there are too many characteristics of the former that are too unique to be perceived merely as a sui generis contract of employment.

\subsubsection{Highly personal services of a unique athletic nature}

Le Roux ${ }^{11}$ has stated that "the attraction of sport is the uncertainty of the result. That is perhaps the one feature that distinguishes it from other forms of entertainment where the scriptwriter or director predetermines the outcome. Inherent to the success of sport is the existence of the competition. This is also what distinguishes sport from any other form of business." Blackshaw agrees with this, stating that "the uncertainty of outcome of sporting competition... is the very nature and attractive aspect of sporting endeavour." 12 If the performance regulated by the contract in question is unique, it may be argued that so too is the contract regulating the relationship.

The statements above (that the attraction of sport lies in the uncertainty of the result) underlie the first feature which distinguishes sport from other forms of entertainment. The result is uncertain because of the fact that people with more-or-less equal athletic abilities (all of them unique) compete against each other by exhibiting their athletic skills. Although the initial argument as to these special skills possessed by an athlete was raised in an English case, ${ }^{13}$ the exact same argument has been raised in South African case law. In Dempster v Addington Football $C l u b^{14}$ the athlete's contract in question demanded from the athlete to do the following:

(a) "Apply his mind and body diligently to the art of association football.

(b) Attend all training sessions and matches and all other functions as directed, and at the sole discretion of the team manager, in regard to professional soccer."

The first requirement indicates that the physical attributes of the athlete had to be protected to the extent that he would be capable of performing the demanding physical exercises required to play football. Although some other professions also require physical health, none requires the subject to be in such peak physical condition as in the case of sport. This is also the reason why athletes are constantly tested for the presence of prohibited substances in their systems. $^{15}$ 
Because sport involves activity of a physical nature, it would be unfair towards competitors if athletes were to enhance their physical attributes in an unnatural manner. ${ }^{16}$ This fact distinguishes sport from any other profession, in which employees would be expected to improve their performance by any legal means (which is to say means that are not criminal in nature) necessary. An athlete who increases his athletic performance by taking stimulants, will most likely be expelled, whereas a regular employee will most likely be rewarded for doing huge amounts of work due to his taking stimulants. The opposite is also true as far as sport is concerned: whereas an athlete should refrain from doing anything to enhance her performance in an unnatural manner, she should also take care not to engage in any type of activity that would lead to the restriction of her abilities. This is why many standard athletes' contracts contain clauses which prohibit athletes from participating in activities which could potentially be detrimental to their physical health and wellbeing. Because of the uniqueness of the athletic skills required by the persons under discussion (Prinsloo ${ }^{17}$ refers to these skills as "unique and extraordinary") the nature of the services in question is obviously also unique. In a word, these services can be described as "highly personal". In the case of Troskie en ' $n$ Ander $v$ Van der Walt, ${ }^{18}$ Wright $\mathrm{J}$ held the following:

"The nature of the services which had to be rendered in the matter at hand, is the playing of rugby for a specific club. The rendering of the relevant services depends not only on the enthusiasm, willingness and perseverance of the player in question, but said services demand a fair amount of expertise, skill and aptitude of a personal nature which will be dependent on the specific player's characteristics and also his relationship with the club for which he plays." 19

The relevance of Wright J's decision to this discussion lies in the very first sentence of the decision. He hints on the fact that the services in question require a significant amount of knowledge and skill of a personal nature, and also that the services in question would demand specific characteristics (as well as capabilities) of the athlete.

Foxcroft J in Santos Professional Football Club (Pty) Ltd v Igesund and Another ${ }^{20}$ made great strides towards indicating that the contract in question was not an ordinary contract of employment. In fact, the decision has led to some scrutiny, most notably by Naudé, ${ }^{21}$ discussed below. Foxcroft $\mathrm{J}$ stated the following:

"It is important, in my view, to bear in mind that this was not a case of an ordinary contract of employment. It differed from an ordinary contract (of employment), both in respect of the signing-on fee and the job description dealt with below."22 
This statement was followed up by the following:

"First respondent in this appeal is certainly no ordinary servant, but a contracting party, contracting on equal terms with applicant, and being able to command a high sum of money to do so. He is also given carte blanche in the exercise of his duties.",23

What made the contract unique as opposed to merely one of employment, according to Foxcroft $\mathrm{J}$, was the fact that it made provision for a "signing-on" fee and that the job description of the professional coach included the fact that the employer-club had no right to prescribe to the coach how to do his job. Naudé ${ }^{24}$ reiterates this characteristic identified by Foxcroft $\mathbf{J}$, by stating that interference by the club in the execution of the professional coach's duties would have led to breach of contract by the club. It is evident that the working relationship did not imply one in which the employee was subordinate to the employer. ${ }^{25}$ Seedat $\mathrm{C}$ in the private arbitration matter of Mmethi and Bloemfontein Celtics Football $C l u b^{26}$ confirmed the possession of "special skills" by professional athletes (and coaches) in no uncertain terms. The arbitrator stated that professional football clubs sought out players with "exceptional talent and deft skills",27 because of the fact that (South African, but certainly also foreign ones of all sporting codes) "rampage for glory.",28

\subsubsection{Equal bargaining power}

Naudé states that the fact that the professional coach in Santos had contracted on equal terms with the club's representatives, and was consequently able to demand a large sum of money for his services, was another sui generis characteristic of the contract in question. ${ }^{29}$ The coach possessed increased bargaining power, based on the fact that he was a "highly successful and respected coach". ${ }^{30}$ There was therefore not a situation where the "employee" was presented with a unilateral contract favouring the employer's interest. ${ }^{31}$ Although the "employee" in this case was a coach, the same principles would apply if he were an athlete. Naudé mentions a potential characteristic that the court did not identify: that if any damages were to be caused by the breach of the type of contract in question, it would be more difficult to quantify than would be the case in ordinary employment sectors. This characteristic would be even more substantial if the party in breach of contract (if such breach were to occur) was very difficult to replace because of the possession of certain "special skills". ${ }^{32}$ Something that must also be kept in mind, according to Naudé, is that the loss of a professional player or coach may even affect the interests of potential sponsors and fans. Once again, damages caused by such loss will be near impossible to calculate. ${ }^{33}$ Because athletes are considered assets to the clubs, 
unions or franchises which they represent, ${ }^{34}$ they certainly do possess increased bargaining power when negotiating the terms of their contracts and thereafter.

\subsubsection{Subjectivity to more than one club at a time and overarching regulations}

Because the contracts of professional athletes are subject to regulations of governing bodies, it sometimes occurs that a professional athlete may at any given time be a party to several athletes' contracts at once. So, for instance, a professional rugby player in South Africa may be a party to contracts with his provincial union, Super Rugby franchise, and his Rugby Championship franchise; ${ }^{35}$ or a professional cricket player may at any given time have a contract with his South African provincial franchise, an Indian Premier League franchise and an English county side. Furthermore, if such a player is selected for the national side, he will enter into yet another athlete's contract with the national body. This is an occurrence which is absolutely unique as far as mercantile law is concerned. No other occupation would create the possibility of a single "employee" being party to up to three different contracts, and yet be required to perform the same type of service in all three. As far as the subjectivity of these contracts to the regulations of governing bodies is concerned, Waglay $\mathrm{J}$ in McCarthy $v$ Sundowns Football Club and Others ${ }^{36}$ made great strides in explaining why the contract in question differed "substantially from the contracts which one finds with other employees." 37 The court stated that a professional footballer (read: professional athlete) may not resign his current employment during the existence of his contract with the employer, without agreement of this (current) employer. Also, even if the contract between the athlete and his current club has expired, the employer still needs to furnish the player with a clearance certificate in order to make the player eligible to play for his new club. ${ }^{38}$ Each and every professional football player in South Africa had (and still has) to sign a standard National Soccer League ${ }^{39}$ Player's Contract as well as a registration form demanding of the player in question to bind himself to the NSL Constitution and Regulations. The contract mentioned is a fixed-term one, which would obviously terminate unless new agreements have been entered into and the player has been registered with his new employer. ${ }^{40}$ All these stipulations, it was argued by Waglay $\mathrm{J}$, contributed to the uniqueness of the contract between a professional, duly registered football player in South Africa and his "employer". The same comments were made by Traverso $\mathrm{J}$ in Coetzee $v$ Comitis $^{41}$ and in Botha $v$ Blue Bulls Company (Pty) Ltd and Another. ${ }^{42 .}$ In the latter case, the contract in question was a standard player's contract subject to a collective agreement between the South African Rugby Players' Association ${ }^{43}$ of which the player (applicant) was a member, and the South African Rugby Employers' Association ${ }^{44}$ 
of which the employer (first respondent) was a member. ${ }^{45}$ Furthermore, the labour relationship between the two parties in question was also subject to the rules and regulations of the International Rugby Board. ${ }^{46}$ The effect of this unique type of contractual agreement is that the athlete's contract is more often than not subject to another, collective contract, and failure to comply with the provisions of the latter would probably render the former invalid.

\subsubsection{Athlete's race to determine value to club}

In the case of Vrystaat Cheetahs (Edms) Beperk v Mapoe and Others, ${ }^{47}$ the applicant argued that because all the rugby unions in South Africa were under a lot of pressure to select black players, they (the applicant) should be granted an order compelling the respondent (a black player) to stay at the union, as it was difficult to find black players of the respondent's calibre. ${ }^{48}$ The applicant would not have been under so much pressure to select the player in question had it not been for the fact that they were subject to the governing body's (The South African Rugby Union's) auspices. This requirement entails that the colour of an athlete's skin may also contribute to the uniqueness of such an athlete, especially in a system that differentiates between athletes based on their racial profiles, like the South African sporting fraternity. It entails furthermore that the contract between an athlete and the club or province that employs him may be significantly influenced by the rules and regulations governing the sport in general.

\subsubsection{Limited professional career}

One of the primary differences between the athlete's contract and the contract of employment is the fact that whereas an employee's professional career lasts the majority of that employee's lifetime, the athlete's professional career is extremely limited. In the private arbitration of Mmethi and Bloemfontein Celtics Football Club, Seedat C stated that football players had a "short productive capacity", which was also subject to a coach's idiosyncrasies and game plans. ${ }^{49}$ This has a direct impact on the question as to the most adequate remedy for breach of an athlete's contract, as discussed later in this article.

\subsection{Do South African authorities perceive athletes' contracts as sui generis?}

According to Hawthorn and Hutchison, ${ }^{50}$ the sui generis theory for determining the nature of a specific contract involves rendering the naturalia ${ }^{51}$ of ordinary contracts inapplicable. ${ }^{52}$ If one considers that the naturalia of a specific contract is an aid to determine the rights and duties of parties to a contract, as well as the effects and consequences of their contract, it is 
clear that the naturalia of a specific contract will determine the nature of such contract. ${ }^{53}$ If the sui generis theory were to be applied in order to determine whether an athlete's contract is sui generis, the naturalia of the ordinary contract of service should be rendered inapplicable. The rights and duties of the parties to an athlete's contract differ from those of the ordinary contract of employment, along with the effects and consequences of such contract. Cooper ${ }^{54}$ states that a contract should be classified by turning on the true intention of the parties thereto, which is to be inferred from the purpose of the agreement. According to the sui generis theory, this means that the athlete's contract, while possessing attributes of the ordinary contract of employment, is sui generis, because the purpose or object of the athlete's contract differs from that of the ordinary contract of employment.

This ultimately means that South African courts should, when considering the most adequate remedy for breach of athletes' contracts in future, be heedful of the fact that they are dealing with breach of a very unique type of contract. The sui generis nature of athletes' contracts should be the primary indicator that specific performance is the most adequate remedy for breach thereof. Ironically enough, some of the sui generis characteristics discussed above have been used by South African courts as motivation not to grant an order of specific performance.

\section{South African courts' viewpoint on the most adequate remedy for breach of athletes' contracts to date}

South African case law on the most adequate remedy for breach of athletes' contracts in particular is very limited, and contradictory at best. In order to illustrate the need for clarity on the most adequate remedy for breach of athletes' contracts, the most significant South African decisions on the matter are consequently discussed. This discussion is limited to cases that deal particularly with breach of athletes' contracts, and not contracts of personal services in general.

In the case of Highlands Park Football Club Ltd v Viljoen and Another, ${ }^{55}$ the applicant club sought an interdict against the second respondent barring the latter from playing professional football for any club in South Africa other than the applicant. ${ }^{56}$ The order was sought based on a clause in the original contract between the second applicant and the second respondent, which basically constituted a restraint of trade applicable to the latter after the contract had come to an end. ${ }^{57}$ The court decided that it was unreasonable to prevent the second 
respondent from plying his trade elsewhere in South Africa. In reaching its decision, the court depended on certain principles of labour law which suggested that an employee should not be "debarred from exercising his skills, knowledge and service to the advantage of both himself and the State." 58 Furthermore, the court decided that "a man's aptitudes, his skill, his dexterity and his manual and mental ability are not his master's property, but his own."59 Finally, the court stated that an employer could not protect himself from his servant's competition after the contract of employment had already expired. ${ }^{60}$ Consequently, the court refused to grant the interdict sought.

The first problem with the decision in Highlands Park is that, by the court's own admission, there were no precedents pertaining to restraints of trade in athletes' contracts in particular. ${ }^{61}$ Therefore, legal principles pertaining to restraints of trade in general were applied. As explained above, the sui generis nature of the athlete's contract requires special heed to be taken of the unique characteristics of athletes' contracts when deciding on the most adequate remedy for breach thereof.

The second problem relates to the court's reasoning. It was argued by counsel for the applicant that a significant amount of "training, teaching and know-how" had been "built" into the second respondent and that that fact constituted certain "special circumstances" that would apply in favour of a restraint of trade being enforced. ${ }^{62}$ The court disagreed that this was a consideration at all, and decided that "these attributes are precisely what the authorities, correctly in my opinion, say the servant can take away with him without restriction after leaving his master's service." 63 It has since become trite as far as athletes' contracts are concerned, that clubs may indeed expect remuneration for investing time and money in its players. It is therefore submitted that the decision in Highlands Park, as far as it relates to adequate remedies for breach of athletes' contracts as well as the nature of these contracts, is archaic and ill-informed as far as it relates to the treatment of athletes' contracts - even at the time of the decision. As a matter of fact, the reasons advanced for not granting the interdict in question may hypothetically be advanced in favour of an order of specific performance.

The decision of Troskie en ' $n$ Ander $v$ Van der Walt ${ }^{64}$ was the first in South Africa in which a court had to decide on whether specific performance would be an adequate remedy for breach of an athlete's contract. 
The first appellant and the respondent had entered into a contract which basically obliged the respondent to play rugby for the second appellant (Old Greys Rugby Football Club) for the entire 1991 season. In return, the respondent was to be paid the amount of R4 $000 .{ }^{65}$ As it turned out, the respondent joined the opposing Collegians-club on 18 February 1991, with the intention of forthwith playing his club rugby for that particular club.

The creditor (Troskie in his personal capacity and on behalf of the Old Greys club) applied for an order compelling the debtor (Van der Walt) to play for the Old Greys club for the course of the 1991-season. In essence, the appellant sought an order for specific performance of the obligations in question. The question which had to be answered, was whether a court could order specific performance of a contractual obligation that will essentially compel a rugby player to play for a team for which he was unwilling to play. Wright $\mathrm{J}$, writing on behalf of the full bench, held the following: ${ }^{66}$

The nature of the services which had to be rendered in the current case, is the playing of rugby for a specific club. Not only does the rendering of said service depend on the personal enthusiasm, willingness and perseverance of the particular player, but a great deal of know-how, proficiency and skill of a personal nature is also involved, which is dependant on the particular player's specific characteristics as well as his attitude towards the club he plays rugby for. It is highly doubtful whether, in the particular circumstances of this case, an order of specific performance would ever be suitable, regardless of the fact that the amateur code of the International Rugby Board still applies.

In addition, the court $a$ quo in the current case, in the person of Malherbe JP, decided the following: ${ }^{67}$

In my opinion it is a ridiculous prayer an no reasonable Court would grant an order of specific performance of Van der Walt's contractual obligations.

Wright $\mathbf{J}$ emphasises the fact that in the current case an order for specific performance may never be granted, "regardless of the fact that the amateur code of the International Rugby Board still applies."68 By implication, an order for specific performance in similar circumstances would not have been granted, even if rugby had already been a professional sport at the time of the judgment.

The Troskie-decision had a significant influence on consequent decisions with similar facts in the professional era of sport. In Santos Professional Football Club (Pty) Ltd v Igesund and Another ${ }^{69}$ the court had to decide whether to compel a professional football coach to honour the fixed-term contract with his club. ${ }^{70}$ The coach (first respondent) received a better offer from another club midway through his current contract. He repudiated the contract by 
entering into a different one with the new club. The contract between the coach and his original club (the applicant) contained a clause which made express provision for specific performance in case of breach of contract. ${ }^{71}$ Desai $\mathbf{J}$ decided, however, that an order for specific performance of the coach's obligations could not be granted. The reasons were firstly that the coach, if compelled to serve out his contract, would render his duties with diminished enthusiasm and commitment. ${ }^{72}$ Secondly, it would be impossible for the court to supervise whether the coach was obeying the order of specific performance. If an order of specific performance were granted against the coach, it would probably compromise his dignity. ${ }^{73}$ The court also alluded to other "compelling reasons" not to enforce specific performance, including a "disapproval of forced labour, the fact that damages appear to be a sufficient remedy for an employer and simply a reluctance to interfere with an employee's right to freely exercise his or her skills or profession." 74

The Full Bench of the Cape High Court ${ }^{75}$ reached an altogether very different decision. Foxcroft $\mathrm{J}$ on behalf of the Full Bench stressed the fact that the contract in question was no ordinary contract of employment. ${ }^{76}$ In fact, the coach in question (first respondent) had contracted on equal terms with the club (applicant) and was given carte blanche in the exercise of his duties. ${ }^{77}$ In answer to the question of whether specific performance would be an adequate remedy for breach of the contract in question, the court stated that it was the injured party's (in this case, the applicant club) right to elect whether to hold a defendant to his contract and claim specific performance, and not the defendant's. ${ }^{78}$ The court also decided that ordering specific performance of a contract involving service of a very personal nature, would have the same effect of a negative injunction as granted in the case of Lumley $v$ Wagner discussed below. ${ }^{79}$ In response to the court a quo's decision that supervision of the order of specific perofrmance would be difficult, the Full Bench quoted Treitel ${ }^{80}$ in deciding that the "difficulty of supervision is much exagerated." 81 Finally, the court found that the applicant carried the risk of the respondent's not functioning optimally in terms of an order of specific performance. Subsequently, the court had no hesitation in ordering specific performance of the contract in question. In summary, Naudè ${ }^{82}$ states that there were four main reasons why the court granted an order of specific performance in Santos: firstly, the contract was not an ordinary contract of employment; secondly, specific performance is considered the primary remedy for breach of contract in South African law; thirdly, the relationship between the parties had not broken down irretrievably - the coach's principal reason for leaving was a commercial one, and fourthly, the court held that "practical 
considerations" were irrelevant to the court's equitable discretion to refuse specific performance, which should only be based on "recognised hardship to the defaulting party."

Although the Full Bench's decision in Santos was a step in the right direction, ${ }^{83}$ the contract in question, while similar in nature, was not an athlete's contract per se. The question as to the most adequate remedy for breach of athletes' contracts has not come before the SCA yet. The contribution this article attempts to make is to suggest to South African courts (especially the SCA) that specific performance should be ordered in case of breach of athletes' contracts, if the surrounding circumstances and facts lend themselves thereto. To substantiate this suggestion, the viewpoint of US authorities (especially case law and authoratitive articles) on the most adequate remedy for breach of athletes' contracts will consequently be discussed.

What is especially relevant about the following discussion, is the fact that while US courts have always maintained that either negative injunction or damages is the most adequate remedy for breach of athletes' contracts, some US authorities have started advocating for positive injunction (specific performance) as the most adequate remedy for that purpose.

\section{US authorities' viewpoint on the most adequate remedy for breach of athletes' contracts}

\subsection{The Lumley rule}

The viewpoint of US courts on the most adequate remedy for breach of athletes' contracts is governed by the rule laid down in Lumley $v$ Wagner. ${ }^{84}$ In this case, which is considered the locus classicus in common law as far as determining the most adequate remedy for breach of contracts of personal services is concerned, the father of a minor woman, acting on the latter's behalf, had entered into a contract with the manager of Her Majesty's Theatre in London to perform six operas at said theatre. ${ }^{85}$ The contract contained a clause which specifically forbade the woman to "use her talents at any other theatre, or in any other concert or reunion, public or private, without the written consent of the manager." ${ }^{, 86}$ It was evident from the contents of the contract that the "master and servant"-relationship did not apply to the current circumstances. The court made specific mention of the unique nature of the woman in question's talent. In considering the most adequate remedy for breach of contract (the woman, through the representation of her father, subsequently committed breach of contract by entering into an agreement with another theatre company, and in doing so repudiated the contract with the manager of Her Majesty's Theatre), the court stated the following: ${ }^{87}$ 
"The Courts have granted injunctions to restrain the sale of goods contrary to a prohibitory clause of an agreement, but it never has restrained an actor or a singer, for this reason that it cannot compel the specific performance and make a Defendant act or sing."

The court found that specific performance would probably not be the most adequate remedy for breach of a contract requiring services of a very personal nature. ${ }^{88}$ However, the court had no objection to ordering a negative injunction to prevent the person in breach from "competing in other personal services arrangements". ${ }^{89}$ It is submitted, however, that the purpose of negative injunction is to indirectly ensure specific performance of the contract.

\subsection{Relevant US decisions on the most adequate remedy for breach of athletes' contracts}

This is not meant to be an exhaustive discussion of all US decisions on the most adequate remedy for breach of athletes' contracts. Landmark decisions are discussed in order to ascertain the general point of view of US courts on the matter at hand. No court in the US has ever granted specific performance of an athlete's contract. However, the courts' arguments and those of academics within the US weigh heavily in favour of granting specific performance as remedy for breach of athletes' contracts.

Shortly after the founding of the first professional baseball league (the National League), the first reported case in the US which commented not only on the nature of the athlete's contract, but also on the most adequate remedy for breach thereof was decided. The Pennsylvania Circuit Court in Allegheny Base-ball Club v Bennett ${ }^{90}$ depended heavily on English law insofar as the most adequate remedy for breach of a contract involving personal services was concerned. The contract in question was not one of "employment", but in fact a type of "pre-contractual agreement". In terms of the contract, the professional athlete (one Charles Bennett) agreed to execute a formal contract to provide personal services as a baseball player to the complainant in future. ${ }^{91}$ The relevance of the decision lies in the fact that the court commented on the nature of the eventual contract (for the playing of professional sport) and the most suitable remedy for breach of that type of contract. The content of the athlete's contract was simple: the athlete was obliged to provide his services as a baseball player to the Allegheny Club for the 1883 season. In return, the latter would pay the athlete the amount of $\$ 1,700$ for the season. ${ }^{92}$ The complainant argued that it (the complainant) was in the "business of playing baseball for profit" and that this demanded "expenditure of much time and large sums of money...to make preparations for the exhibition of such games." 93 Furthermore, the complainant stated specifically that the 
respondent (the athlete) was a "skilful player of baseball" and that by subsequently signing a contract with another club, ${ }^{94}$ the complainant would suffer damages in the amount of "not less than $\$ 1000 . " 95$ Although the club stated that it would suffer the damages referred to, it requested the court to compel the athlete to sign the eventual contract in terms of which professional athletic services had to be rendered to the club, and also to restrain the athlete from performing these services for any competing club. ${ }^{96}$ Very importantly, in considering these remedies, the court made mention of the nature of the contract between a professional sports club and a professional athlete in such a club's employment. The first and most logical assumption made by the court was that the contract in question was one of "personal services, where the services in question require a succession of acts whose performance cannot be accumulated by one transaction, but will be continuous and require the exercise of special knowledge, skill or judgment." ${ }^{, 97}$ This is a clear reference to the athlete's contract as sui generis legal tool. The services in question are not only personal (as in all contracts of employment) but require special knowledge, skill and judgment of an athletic or sporting nature. In deciding on the most adequate remedy for breach of this type of contract, the court stated that there was no precedent where a contract for personal services alone had been enforced actively. ${ }^{98}$ In other words, while the court acknowledged the sui generis nature of the services in question as well as of the contract regulating those services, it was decided that equity would demand that specific performance ${ }^{99}$ of the contract in question would not be granted. ${ }^{100}$ The reason was that the complainant already had at its disposal a remedy in law (damages). What the court in Allegheny failed to take into account, though, was that in the case of a professional athlete contracting with a club, there was indeed mutuality, as the two parties had negotiated and contracted on equal footing. Secondly, there rests no duty of superintendence of a court order on the court who had decreed such an order: the risk of the order not being performed adequately is carried by the party who had requested that order in the first place. It is submitted that in the Allegheny case, the court followed English doctrine blindly, without considering the true nature of the contract in question and the effect that such consideration should have had on deciding the most suitable remedy in the circumstances.

The nature of the athlete's contract as perceived by courts within the various US jurisdictions was discussed in detail for the first time in the all-important case of Philadelphia Ball Club $v$ Lajoie. ${ }^{101}$ In this case, a professional baseball player violated his agreement with the club that employed him by arranging to play for a rival club. ${ }^{102}$ Although the trial court had "with great industry and painstaking care collected and reviewed the English and US decisions" 103 on the 
question at hand, the Supreme Court of Pennsylvania in the person of Potter $J$ for the first time in the history of professional sport in the US investigated the true nature of the athlete's contract. It came to a conclusion directly contrary to the decision in Allegheny as far as the most adequate remedy for breach thereof was concerned.

In Lajoie, ${ }^{104}$ the court stated that the athlete in question had for several years been in the service of the plaintiff club, and had been re-engaged by said club from season to season with an ever-increasing salary. ${ }^{105}$ The athlete had become thoroughly familiar with the action and methods of the other players in the club, and furthermore his own "work" was described by the court as "peculiarly meritorious as an integral part of the team work which is so essential." 106 Additionally, the court stated that the athlete's services were of peculiar and special value to the plaintiff, and not easily replaceable (as opposed to entirely irreplaceable). Lastly, the court stated that because the athlete was "well-known" and had a "great reputation among the patrons of the sport", he was a "most attractive drawing card for the public." ${ }^{107}$ In somewhat dramatic fashion, the court concluded its praise of the athlete in question by stating that he (the athlete) was "not the sun in the baseball firmament, but...certainly a bright particular star." 108 The point that the court was so gallantly attempting to make, was that the services performed by the athlete in question were of a sui generis athletic nature. Because of the nature of these services and the attractive way in which the athlete performed them, the latter had become invaluable to his employer-club, not least so because of the tremendous amount of income he generated for the club. Rogers ${ }^{109}$ describes the athlete in question (Napoleon Lajoie) as "arguably the first superstar of the Twentieth Century." Although Whitehill ${ }^{110}$ states that as a general rule, personal service contracts will not be specifically enforced, ${ }^{111}$ in his discussion of Lajoie he establishes the necessary prerequisites for obtaining negative injunction against a breaching athlete. ${ }^{112}$ These are that the athlete in question should possess a "sufficiently unique ability, an adequate remedy at law, and irreparable harm to the plaintiff." 113 If the first of these prerequisites is complied with, in other words once an athlete has been shown to be "sufficiently unique", the remedy of damages will always be inadequate in case of breach of contract by the athlete. ${ }^{114}$ Whitehill opines that inadequacy of the remedy of damages is always equated with irreparable harm to the aggrieved club. ${ }^{115}$ In other words, once an athlete has been found "sufficiently unique" in his sporting code, damages would be an inadequate remedy for breach of contract committed by such athlete against his club, and the club would suffer irreparable harm as a result of the athlete's breach of contract. The position adopted in Lajoie as far as the treatment of the 
athlete's contract is concerned, was that such contract was sui generis, as it regulated services of a sui generis nature. Despite the fact that the Pennsylvania Supreme Court acknowledged English law's perception that personal services contracts would never be specifically enforced, it found that the athlete's contract is so unique as to qualify as something very different from a mere "personal services contract", and therefore demanded a remedy other than damages for breach of said contract. While this remedy was not specific performance, the decision certainly paved the way for future US courts granting specific performance based on the sui generis nature of the athlete's contract.

In the preceding case of Columbus Base Ball Clubv Reiley, ${ }^{116}$ the Court of Common Pleas of Ohio decided that "a court of equity will not enforce a contract of personal services... unless the services contracted for were peculiar, unique, and extraordinary in nature, and the person sought to be enjoined is shown to be a person of exceptional skill and ability, so that his place could not reasonably be filled..." ${ }^{117}$ In the case of Lajoie, negative injunction was perceived as the most appropriate remedy for breach of the athlete's contract in question. Although this was a step in the right direction, it is submitted that negative injunction is far more restrictive than would the remedy of specific performance (or affirmative injunction in the US context) be in a case where an athlete commits breach of contract with his club. The reason for this submission is the fact that in case of specific performance, the athlete is still provided the opportunity to ply his trade, albeit at a club he no longer wishes to be a member of. In the case of negative injunction, however, the athlete is barred from plying his trade at any competing club. Although the outcome will be the same (the athlete will be compelled to ply his trade at his current club even though the current club might no longer be interested in his services), it is submitted that there is a strong possibility that negative injunction would be considered unconstitutional in South African law, as it would possibly infringe on a person's constitutional right to freedom of trade, occupation and profession awarded in section 22 of the Constitution of the Republic of South Africa. In order to make this comparative study feasible, the possibility of US courts granting affirmative injunction (in effect specific performance of the contractual obligations) of athletes' contracts must be investigated. This contribution is aimed after all at suggesting to South African courts that specific performance (and not "negative injunction" or a prohibitive interdict) is the most adequate remedy for breach of athletes' contracts. 
Brennan states that although specific performance has traditionally been considered an extraordinary remedy for breach of contract, the "trend" in the various US jurisdictions is to make specific performance more readily available as an alternative remedy for breach of contract. ${ }^{118}$ Rapp $^{119}$ agrees with this, arguing that "this long-standing (Lumley-) rule should be modified in the case of athletic employment contracts." According to Rapp, four arguments are usually raised for courts' refusal to order specific performance in employment matters: the perception of an affirmative injunction as a "false remedy" that would cause substandard performance by the defendant; judicial monitoring and post-injunctive enforcement proceedings to ensure proper performance by the defendant; the fact that affirmative injunctions supposedly violates the Thirteenth Amendment, ${ }^{120}$ and lastly the fact that affirmative injunction would create strong bilateral monopoly in favour of the "employer". Rapp exclaims that "none of these rationales is compelling in the context of athletic employment arrangements." 121 It is very difficult for professional athletes to provide service at less than their full abilities, as the athlete-club relationship has certain "built-in incentives" to ensure optimal performance. ${ }^{122}$ Statistics as to athletes' performances are readily available and more quantifiable than other fields. The argument that affirmative injunctions are unconstitutional has rarely been tested in US courts and seems, according to Rapp, "contrary to the intent of the framers of the Thirteenth Amendment" as far as it relates to athletes' contracts. ${ }^{123}$ Furthermore, Rapp feels that market imperfections which prevent Coasian post-injunction bargaining in typical employment relationships are more limited in the professional athletics context. ${ }^{124}$ While arguing that affirmative injunction is the most adequate remedy for breach of athletes' contracts, Rapp simultaneously argues that both damages and negative injunctions are inadequate remedies for breach of these contracts. As far as damages are concerned, the obvious problem exists that it is almost impossible to determine a fair amount of damages in case of breach of athletes' contracts: "the services of a player are extremely difficult to value and impossible to prove." ${ }^{\prime 25}$ Damages as a remedy for breach of the athlete's contract was in fact described by the court in Boston Professional Hockey Association $v$ Cheevers ${ }^{126}$ as being "speculative, uncertain, and as a practical matter, impossible to ascertain." Johnson ${ }^{127}$ adds that players' services are extremely difficult to value and impossible to prove. As far as negative injunctions are concerned, they are not perceived as "a very powerful remedy", and "lacks teeth as remedy for athletes opportunistically demanding contract renegotiation". ${ }^{128}$ What is more, a negative injunction would only be effective where an athlete is pursuing employment opportunities with other potential employers. ${ }^{129}$ Finally, negative injunctions have "little social utility, except as 
deterrent against player holdouts". ${ }^{130}$ The philosophy underlying this clear move towards affirmative injunction against athletes' repudiating their contracts is not new to US law at all. As a matter of fact, it was already recognized in the case of American Association Baseball $C l u b v$ Picket $^{131}$ that a player's promise to play for a particular team reflected a prohibition against playing for any other. In fact, the court in Picket stated that "every express promise not to do an act embraces within its scope an implied promise not to do anything which will prevent the promisor from doing the act he has engaged to do." 132

Rapp's argument in favour of specific performance as remedy for breach of athletes' contracts in the US is not an isolated one. Wichmann ${ }^{133}$ states that (US) courts do not generally utilise the remedy of "traditional specific performance", unless it appears that "damages will not make the plaintiff whole". If an athlete is considered "sufficiently unique", no other remedy but specific performance would "make the plaintiff whole". The uniqueness of an athlete plays an important part in a court's decision to order injunctive relief (especially affirmative injunction) to the club employing such an athlete, should the latter repudiate. If, as decided in Lajoie, it would be difficult to replace the specific athlete, such athlete would probably be considered sufficiently unique in an athletic sense, ${ }^{134}$ which would justify an affirmative injunction in case of breach of contract. Whitehill adds that the factor to be considered is the relative value of the athlete to his team, and not simply his past record or reputation as a professional athlete. ${ }^{135}$ This was not difficult to determine in Lajoie, but it should be kept in mind that not all athletes are considered as stellar as Napoleon Lajoie. In Central New York Basketball, Inc. v Barnett, ${ }^{136}$ for instance, the Court of Common Pleas of Ohio decided that a particular basketball player was "sufficiently unique" despite the fact that he had only been a professional athlete for one year and had not been selected for national honours. ${ }^{137}$ The mere fact that the athlete in question was considered good enough at the time to play in the NBA was sufficient reason for such athlete to be qualified as one possessing "excellence and extraordinary abilities." 138 Importantly, the fact that both teams (the current team he was playing for as well as the team he wanted to defect to) were offering the athlete a substantial raise in salary, was also indicative of the fact that the athlete possessed "special value". 139

At least two US courts have subsequently confirmed the decisions in both Lajoie and Barnett as far as the "difficult-to-replace"- requirement ${ }^{140}$ for granting either specific performance of an athlete's contract or negative injunction against the athlete is concerned. Interestingly 
enough, Whitehill states that both these decisions have been criticised for abandoning the standards and limits set in Lajoie.

The first of the two mentioned cases was Winnipeg Rugby Football Club v Freeman, ${ }^{141}$ in which two rugby football players attempted to repudiate their contracts to play in the Canadian Football League by signing contracts with the Cleveland Browns, which participated in the NFL. ${ }^{142}$ The court granted negative injunction against both players, preventing them from committing breach of their respective contracts. The court's decision was based on the "uniqueness"-requirement used in Lajoie, although it was argued that the two players in question both possessed little more than "ordinary" talent by NFL standards. The court found, however, that by Canadian Football League standards, the two players both possessed exceptional athletic abilities. ${ }^{143}$ Brennan ${ }^{144}$ describes these abilities as "peculiar to the Winnipeg Club", implying that the exceptionality of their athletic skills were perceived in context. It must be gathered, then, from the court's decision in Freeman that the "uniqueness" requirement should be perceived as relating to the value that the current employer-club, union or province attaches to the athlete in question. The uniqueness- requirement for ordering specific performance was developed further in the case of Dallas Cowboys Football Club Inc. $v$ Harris. ${ }^{145}$ In this case, the court decided that a player who possessed only average ability at the relevant sporting code complied with the "uniqueness"-requirement. The player in question was, based on that requirement, prevented from repudiating his current contract. ${ }^{146}$ The court decided that the athlete in question was the most skilled player in his position available to the plaintiff at the time, and therefore the player's uniqueness was said to be measured relative to his value to his specific club, and not to his general status as professional athlete.

As far as the requirement of uniqueness is concerned, US courts seem to be in agreement that an athlete will be considered unique if such athlete cannot easily be replaced by his professional employer-club. ${ }^{147}$ According to Uberstine and Grad, ${ }^{148}$ this entails that "no two athletes are identical in terms of what they can provide to a team." In the case of breach of an athlete's contract, "money damages may be unobtainable due to difficulty in precisely quantifying the value of the athlete's services." "149 Once the "uniqueness test" has been passed, US courts seem to be of the opinion that the loss of the athlete in question will inevitably cause irreparable harm to such a player's employer-club. ${ }^{150}$ The "irreparable harm"- requirement entails that the plaintiff (in this instance, the employer-club) has no 
adequate remedy at law for breach of contract by the employee-athlete. ${ }^{151}$ In other words, the "remedy at law" or damages is considered inadequate for breach of athletes' contracts. In many instances, however, the services of the breaching athlete may be easily replaceable to the degree that the employer-club would not suffer irreparable harm and damages would be sufficient and ascertainable. This will rarely be the case in professional sport. The fact that the athlete in question is a professional, suggests that such athlete is sufficiently unique in the way he plies his trade. This has been confirmed in the Barnett-case discussed above. ${ }^{152}$

US authorities perceive the athlete's contract as something very different from a mere contract of personal services. While damages may be the most appropriate remedy for breach of the latter, specific performance (even indirectly by way of a negative injunction) would be the most suitable remedy for breach of the former. It seems from the abovementioned discussion that US perceptions of specific performance as most adequate remedy for breach of athletes' contracts has come full circle. Indeed, during the colonial and revolutionary periods of American history, personal service contracts such as apprenticeships and indentures could be enforced in a variety of ways, including specific performance. ${ }^{153}$

\section{Conclusion}

Despite US courts' governance by the Lumley rule when having to decide on the most adequate remedy for breach of athletes' contracts, authoritative US authors have in the past few years advocated for affirmative injunction which would have the effect of specific performance for breach of athletes' contracts. Because of contradictory South African decisions on the most adequate remedy of athletes' contracts, along with South Africa's relative immaturity as far as this topic is concerned, it is suggested that South African courts pay heed to the approach adopted by relevant US authorities. The US has a rich history of litigation as a result of breach of athletes' contracts, and the point of view adopted by US authorities is based on the athlete's contract as sui generis legal tool. It is suggested that South African courts in future (especially the Supreme Court of Appeal, should a similar matter appear before it) should base their points of view on the most adequate remedy for breach of athletes' contracts on this fact (the sui generis nature of the athlete's contract) rather than the fact that specific performance is considered the primary remedy for breach of contract in South African law. The athlete's contract is after all not something that is unique to a specific code, country or jurisdiction. It is a bona fide global legal tool. 
1 "SCA"

2003 (5) SA 73 (C).

3 "US".

${ }^{4}$ Most significantly Rapp "Affirmative injunctions in athletic employment contracts: rethinking the place of the Lumley rule in American sports law" (2006) Marquette Sports Law Review 261; Uberstine and Grad "The enforceability of sports contracts: a practitioner's playbook" 1987 Loyola Entertainment and Law Journal 1 and Whitehill "Enforceability of professional sports contracts - what's the harm in it?" 1981-1982 Southwest Law Journal 803 among others.

${ }^{5}$ The Lumley rule is derived from the case of Lumley $v$ Wagner 42 E.R. 687 (1910), decided in 1852. The rule proclaims that courts will refuse to order affirmative injunctions in relations involving personal services, such as the playing of sport. These courts will, however, issue negative injunction, which has the effect of denying the person against whom the injunction is issued the opportunity of participating in competition with his or her current employer.

${ }^{6}$ According to Champion, the "Standard Player's Contract" in US sport is an employment contract that specifies the player in question's rights. The contract states specifically that the player in question possesses unique skills and that the activities of the player are controlled by the team.

${ }^{7}$ Rapp "Affirmative injunctions in athletic employment contracts: rethinking the place of the Lumley rule in American sports law" (2006) Marquette Sports Law Review. 261 at p. 263.

${ }^{8}$ The wording here is based on the standard NFL Player Contract retrieved from the National Football League's website, www.nfl.com, on 15 February 2016.

${ }^{9}$ Most notably in Dempster v Addington Football Club (Pty) Ltd 19673 SA 262 265; Highlands Park Football Club Ltd v Viljoen and Another 19783 SA 191 (W) 192; Santos Professional Football Club (Pty) Ltd v Igesund and Another 20035 SA 73 (C) 79; Louw, A (2012) Sports Law in South Africa, $2^{\text {nd }}$ ed, p. 222.

${ }^{10}$ Louw (2012, pp. 234-235).

${ }^{11}$ Le Roux (2002) "Under starter's orders: Law, Labour law and Sport" International Law Journal p. 23. See in this regard also Smailes (2007) "Sports law and labour law in the age of (rugby) professionalism: collective power, collective strength" Industrial Law Journal p. 57.

12 Blackshaw (2013) "Match fixing in sport: a top priority and ongoing challenge for sports governing bodies" De Jure 945 at p. 948.

${ }^{13}$ Walker v Crystal Palace Football Club [1910] 1 KB 87.

1419673 SA 262 (D).

${ }^{15}$ The purpose of the World Anti-doping Code is to "protect the athletes' fundamental right to participate in drug-free sport and thus promote health, fairness and equality for athletes worldwide." This purpose is reiterated in article 2 of the South African Institute for Drug-Free Sport's (SAIDS) Anti-doping rules, which states that "it is each athlete's personal duty to ensure that no prohibited substance enters his or her body. Athletes are responsible for any prohibited substance or its metabolites or markers found to be present in their samples. Accordingly, it is not necessary that intent, fault, negligence or knowing use on the athlete's part be demonstrated in order to establish an anti-doping rule violation..."

${ }^{16}$ Whereas an athlete should not enhance his performance through unnatural means, he is obviously free to enhance his physical skills through natural means, such as better training opportunities, coaching, etcetera. In the case of Golden Lions Rugby Union v Venter, unreported case number 2007 of 2000, the court decided that factors such as superior coaching staff and the opportunity to train on the beach and swim in the sea provided sufficient motivation for an athlete to change clubs. In no profession other than sport would better opportunities to improve one's physical condition and attributes be regarded as sufficient grounds to move from one "employer" to another by a court of law.

${ }^{17}$ Prinsloo (2002) "Enkele opmerkings oor spelerskontrakte in professionele spansport" Tydskrif vir SuidAfrikaanse Reg 229 at p. 232.

1819943 SA 545.

${ }^{19}$ Troskie en 'n Ander v Van der Walt 19943 SA 545552.

20035 SA 697 (C).

${ }^{21}$ Naudé (2003) "Specific performance against an employee. Santos Professional Football Club Ltd v Igesund" South African Law Journal 269. Le Roux (2003) South African Mercantile Law Jounal 116 also provides some valuable input on the decision in question.

${ }^{22}$ Santos Professional Football Club (Pty) Ltd v Igesund and Another 20035 SA 73 (C) at p. 76.

${ }^{23}$ Santos Professional Football Club (Pty) Ltd v lgesund and Another 20035 SA 73 (C) at p. 79.

${ }^{24}$ Naudé (2003) South African Law Journal at p. 271. 
25 Ibid.

${ }^{26}$ (2012) 33 ILJ 1307 (ARB).

${ }^{27}$ Mmethi and Bloemfontein Celtics Football Club (2012) 33 ILJ 1307 (ARB) at 1317.

28 Ibid.

${ }^{29}$ Naudé (2003) South African Law Journal at p. 271.

30 Ibid.

31 Ibid. This rang true to what Louw (2012) at p. 215 describes as follows: "In line with developments elsewhere, and in parallel with more general developments in South African society and its new constitutional order in the movement towards democracy, freedom and respect for human rights, South African employment law saw the development of a more rights-based approach to the employment relationship in a bid to counter the traditionally strong employer-biased relationship occasioned by the nature of the common law contract of employment." Whereas it is agreed with Louw that there has indeed been a shift of focus, the culture of the "strong employer-biased relationship" is still very problematic as far as labour relations are concerned. In the case of SARPA on behalf of Bands \& Others v SA Rugby (Pty) Ltd (2005) 26 ILJ 176 (CCMA); [2005] 2 BALR 209 (CCMA) it was argued that because the contract of a professional rugby player in South Africa is a standard one, players could not really negotiate the terms of their contract, and had to accept most of the contents as it stood.

${ }^{32}$ Naudé (2003) South African Law Journal at p. 272.

33 Ibid.

${ }^{34}$ In Highlands Park Football Club Ltd v Viljoen and Another 19783 SA 191 (W) at p. 192 the court stated that "the applicant's (Highlands Park Football Club Ltd) only assets consist of contractual rights which bind its football players to play football for the applicant. These rights are commonly regarded as cedable and saleable amongst football clubs."

35 The Rugby Championship is an annual one competed between the top provincial sides of South Africa, New Zealand ,Australia, Argentina and Japan.

${ }^{36}$ Unreported case number $\mathrm{J} 4373$ of 2002, delivered in the Labour Court on 30 September 2002.

${ }^{37}$ McCarthy $v$ Sundowns Football Club (Pty) Ltd and Others at 4.

38 Ibid.

39 Widely known by its acronym, "NSL".

${ }^{40}$ McCarthy $v$ Sundowns Football Club (Pty) Ltd and Others at 4.

4120011 SA 1254 (C).

42 Unreported case number JR1965/2005, delivered by the Labour Court of South Africa on 27 June 2008.

43 SARPA.

44 SAREO.

${ }^{45}$ Botha $v$ Blue Bulls Company (Pty) Ltd and Another at 15.

46 IRB.

47 Unreported case number 4587/2010 delivered by the High Court on 29 September 2010. For a case discussion, see Mould (2011) "The suitability of the remedy of specific performance to breach of a 'player's contract' with specific reference to the Mapoe and Santos cases" Potchefstroom Electronic Law Review at p. 189.

${ }^{48}$ Vrystaat Cheetahs (Edms) Beperk v Mapoe and Others 4587/2010 at 24-25.

${ }^{49}$ Mmethi and Bloemfontein Celtics Football Club (2012) 33 ILJ 1307 (ARB) at 1317.

50 Hawthorn, M and Hutchison, D, Labour Tenants and the Law in Murray, C and O' Regan, C (eds) (1990) No place to rest at p. 199.

${ }^{51}$ Naturalia are the legal principles of the law of contract that will apply to such contract in the absence of clauses to that effect in the contract itself. They refer to the terms automatically attached by law to a specific type of contract without them having to be inserted by the parties.

${ }^{52}$ See also Zulu and Others v Van Rensburg and Others 19964 SA 1236 (LCC) 1261. The sui generis theory stands opposed to the absorption theory, which determines that should a specific contract contain characteristics of more than one type of contract, the former should be relegated to the dominant type of contract involved. The combination theory, however, entails that should a specific type of contract contain characteristics of more than one type of contract, the naturalia of each type of contract involved may be applied to the relevant portion of the agreement should this be possible.

${ }^{53}$ Van Huyssteen, LF; Lubbe, GF; Reinecke, MFB (2016) Contract. General Principles, $5^{\text {th }}$ ed. at para. 9.136.

${ }^{54}$ Cooper WE (1973) The South African Law of Landlord and Tenant at p.43.

${ }^{55} 1978$ (3) SA 191 (W). 
${ }^{56}$ Highlands Park Football Club Ltd v Viljoen and Another 1978 (3) SA 191 (W) at p. 192.

${ }^{57}$ The relevant clause read as follows: "The player agrees, undertakes and binds himself that on the expiry of this agreement and unless and until he is formally transferred by the Club to another club, he will not for a period of three years after the date of such expiry play professional football in the Republic of South Africa, save with prior written permission of the Club."

${ }^{58}$ Highlands Park Football Club Ltd v Viljoen and Another 1978 (3) SA 191 (W) 198.

${ }^{59}$ lbid.

${ }^{60} \mathrm{lbid}$.

${ }^{61}$ Ibid at p. 194.

${ }^{62}$ Highlands Park Football Club Ltd v Viljoen and Another 1978 (3) SA 191 (W) 201.

${ }^{63}$ Ibid.

${ }^{64} 1994$ (3) SA 545 (O).

${ }^{65}$ The contract in question was entered into in an era when all levels of rugby union played in South Africa still had to adhere to the amateur code. The contract stated expressly that the respondent was to be paid for playing rugby, which made the contract for all practical and legal purposes void ab initio. See Troskie en 'n Ander v Van der Walt 1994 (3) A 545550.

${ }^{66}$ Troskie en 'n Ander v Van der Walt 1994 (3) SA 545552.

${ }^{67}$ Troskie en 'n Ander $v$ Van der Walt 1994 (3) SA 545553.

${ }^{68}$ Troskie en ' $n$ Ander $v$ Van der Walt 1994 (3) SA 545552.

${ }^{69} 2002$ (5) SA 697 (C).

${ }^{70}$ Santos Professional Football Club (Pty) Ltd v Igesund and Another 2002 (5) SA 697 (C) 700.

${ }^{71}$ Santos Professional Football Club (Pty) Ltd v Igesund and Another 2002 (5) SA 697 (C) 699. The clause read as follows: "9.1. Should the head coach commit any breach of this agreement and fail to remedy such breach within 14 days after registered post of notice from the club or its attorneys requiring the head coach to do so, the club shall have the right to claim forthwith, or to take action against the head coach for specific performance of his obligation under the agreement."

72 Santos Professional Football Club (Pty) Ltd v Igesund and Another 2002 (5) SA 697 (C) 700.

${ }^{73}$ Santos Professional Football Club (Pty) Ltd v Igesund and Another 2002 (5) SA 697 (C) 701.

${ }^{74}$ Ibid at p. 700.

${ }^{75}$ Santos Professional Football Club (Pty) Ltd v Igesund and Another 2003 (5) SA 73 (C) 73.

${ }^{76}$ Ibid at p. 79.

${ }^{77}$ Ibid.

${ }^{78}$ Ibid at p. 81.

${ }^{79}$ Ibid at p. 84.

${ }^{80}$ Treitel (2011) The law of contract $13^{\text {th }}$ ed at 927-931.

${ }^{81}$ Santos Professional Football Club (Pty) Ltd v Igesund and Another 2003 (5) SA 73 (C) 84.

${ }^{82}$ Naudé (2003) "Specific performance against an employee. Santos Professional Football Club Ltd v Igesund" South African Law Journal 269 at 270.

${ }^{83}$ It was confirmed in the case of Vrystaat Cheetahs (Edms) Bpk v Mapoe and Others Case Number 4587/2010 decided on 29 September 2010 in the Free State Provincial Division of the High Court.

${ }^{84} 42$ E.R. 687 (1910).

${ }^{85}$ Lumley $v$ Wagner 42 E.R. 687 at p. 688

${ }^{86}$ Lumley $v$ Wagner 42 E.R. 687 at p. 688.

${ }^{87}$ Ibid at p. 690. This statement found resonance in the decision of Desai J in Santos Professional Football Club $v$ lgesund and Another (2002) 5 SA 697 (C).

${ }^{88}$ A contract of personal services, according to Sagi (2010) "Specific performance of enlistment contracts" Military Law Journal 150 at 151 is described as "a contract in which one of the sides agrees to render to the other side services that are continuous and involve skill, personal labour, and cultivated judgment.

${ }^{89}$ Miller "Hockey's Cold War - Russia's defiance of the IIHF and the Evgeny Malkin Saga" (2007) Seton Hall Journal of Sports \& Entertainment Law 163 at p. 185.

9014 F. 257 C.C. Pa. 1882.

${ }^{91}$ Allegheny Base-ball Club v Bennett 14 F. 257 C.C. Pa. 1882 at p. 257.

92 Ibid.

93 Ibid at pp. 257-258.

${ }^{94}$ The athlete had, after agreeing to sign the contract with Allegheny Club, signed a subsequent contract with the Detroit Baseball Club, a direct competitor of Allegheny. 
${ }^{95}$ Allegheny Base-ball Club v Bennett 14 F. 257 C.C. Pa. 1882 at p. 258.

${ }^{96}$ Ibid.

${ }^{97}$ Allegheny Base-ball Club v Bennett 14 F. 257 C.C. Pa. 1882 at p. 259.

${ }^{98}$ Allegheny Base-ball Club v Bennett 14 F. 257 C.C. Pa. 1882 at p. 260.

${ }^{99}$ Certain guidelines were provided by the court in Allegheny as to the perception of the remedy of specific performance in US law. Firstly, it was decided by the court that specific performance would never be granted

if it is not clear that the minds of the parties have come together, in other words, that consensus existed between them. This relates very closely to the requirement that the agreement between the parties be mutual, its terms certain, its enforcement practicable, and the complainant without an action at law. English influence is notable here, especially as far as the requirement of "mutuality" and the practical challenge of superintendence by the court of its order is concerned.

${ }^{100}$ Allegheny Base-ball Club v Bennett 14 F. 257 C.C. Pa. 1882 at pp. 259-260.

${ }^{101} 202$ Pa. 210, 51 A (1902).

102 Philadelphia Ball Club v Lajoie 202 Pa. 210, 51 A (1902) at pp. 215.

${ }^{103}$ According to the Supreme Court of Pennsylvania on appeal. See Philadelphia Ball Club v Lajoie 202 Pa. 210, $51 \mathrm{~A}(1902)$ at p. 215.

${ }^{104}$ This discussion refers specifically to the Supreme Court's decision.

${ }^{105}$ Philadelphia Ball Club v Lajoie 202 Pa. 210, 51 A (1902) at p. 217.

${ }^{106}$ Ibid.

${ }^{107}$ Ibid.

${ }^{108}$ Ibid.

${ }^{109}$ Rogers, CP (2002) “Napoleon Lajoie, breach of contract and the great Baseball war" Southern Methodist University Law Review at p. 325.

${ }^{110}$ Whitehill, B (1981 - 1982) “Enforceability of professional sports contracts- What's the harm in it?" 19811982 Southwestern Law Journal at p. 803.

${ }^{111}$ The "policy considerations" provided by Whitehill as to why a court in the various US jurisdictions would not grant specific performance, are firstly the difficulty of ensuring proper compliance with a court order, secondly the undesirability of forcing two parties to work together after friction develops between them, and thirdly public sentiment against involuntary servitude. In the same paragraph, Whitehill states however that US and English Courts (like the one in Lumley $v$ Wagner discussed above) have not had any objection to granting negative injunction against a party while the contract is still in force. The question must then be asked why a court would deny someone the opportunity to work somewhere else, but not be willing to compel someone to work for his current employer. Surely the former intrudes to a greater degree on a person's right of trade. See in this regard also Uberstine, GA and Grad, RJ (1987) "The enforceability of sports

contracts: a practitioner's playbook" Loyola Entertainment Law Journal at p. 1.

${ }^{112}$ It must be noted that these prerequisites are not for the remedy of specific performance, but for that of a negative injunction. Whereas the former would compel the respondent in a private law suit to comply with his contract, the latter would simply restrain the respondent to perform the same contractual duties for any employer other than the applicant. It is submitted that whereas the two remedies are certainly different in nature, they will eventually have the same effect: if, for instance, an athlete is prohibited from plying his trade anywhere else, he would have no other option than to remain at the club with which he has entered into a contract.

${ }^{113}$ Whitehill (1981-1982) Southwestern Law Journal at p. 806.

${ }^{114}$ Whitehill (1981-1982) Southwestern Law Journal at p. 806; Uberstine and Grad (1987) Loyola Entertainment Law Journal 11.

${ }^{115}$ Whitehill (1981-1982) Southwestern Law Journal at p. 806.

${ }^{116} 11$ Ohio Dec. 272 (1891).

${ }^{117}$ Columbus Base Ball Club v Reiley 11 Ohio Dec. 272 (1891) at p. 1.

${ }^{118}$ Brennan, JT (1967-1968) “Injunction against professional athletes breaching their contracts" Brooklyn Law. Review at p. 61.

${ }^{119}$ Rapp, GC (2006) "Affirmative injunctions in athletic employment contracts: rethinking the place of the Lumley rule in American sports law" Marquette Sports Law Review 261 at p. 263.

${ }^{120}$ The Thirteenth Amendment of the US Constitution is a prohibition of involuntary servitude and slavery.

${ }^{121}$ Rapp (2006) Marquette Sports Law Review at p. 263. 
122 Ibid.

${ }^{123}$ Ibid. In fact, according to Carton, SF (1998) "Damning with fulsome praise: assessing the uniqueness of an artist or performer as a condition to enjoin performance of personal service contracts in entertainment law" Villanova Sports \& Entertainment Law Journal. 197 at p. 205, the "involuntary servitude" argument was effectively put to rest in Flood v Kuhn 407 U.S. 258 (1972).

124 Ibid.

125 Ibid 269.

${ }^{126} 472$ F.2d 127. (1 ${ }^{\text {st }}$ Cir. 1972).

127 Johnson, AM (1989) "The argument for self-help specific performance: opportunistic renegotiation of players contracts" Connecticut Law Review 61 at p. 62.

${ }^{128}$ Rapp (2006) Marquette Sports Law Review at pp. 270-271.

${ }^{129}$ lbid at p. 270.

${ }^{130}$ Ibid at p. 270. "Player holdouts" are situations where a specific athlete refuses midway through his contract to participate in any team activities, such as training or pre-season training camps. The purpose of such a "holdout" is to negotiate more beneficial contracting terms, but comes down to repudiation of the contract in question by the athlete in question.

${ }^{131} 8$ Pa. C. 232 (C.P. 1890) at 233. See also Carton (1998) Villanova Sports \& Entertainment Law Journal at p. 197.

132 American Association Baseball Club v Pickett, 8 Pa. C. 232 (C.P. 1890) 232.

${ }^{133}$ Wichmann, SC (1999) "Players, owners, and contracts in the NFL: why the self-help specific performance remedy cannot escape the clean hands doctrine" Seattle University Law Review 835 at p. 842.

${ }^{134}$ In fact, Brennan (1967-1968) Brooklyn Law Review 61 at p. 64 states that the athlete's services in this case were so unique as to make it impossible to replace him.

${ }^{135}$ Whitehill (1981-1982) Southwestern Law Journal at p. 808.

13619 Ohio Op. 2d 130, 181 N.E.2d 506 (1961).

${ }^{137}$ Central New York Basketball, Inc. v Barnett 19 Ohio Op. 2d 130, 181 N.E.2d 506 (1961) at 514.

${ }^{138}$ Central New York Basketball, Inc. v Barnett 19 Ohio Op. 2d 130, 181 N.E.2d 506 (1961) at 514; Whitehill (1981-1982) Southwestern Law Journal at p. 808.

${ }^{139}$ Central New York Basketball, Inc. v Barnett 19 Ohio Op. 2d 130, 181 N.E.2d 506 (1961) at 514.

${ }^{140}$ This requirement entails that a club, province or union need not prove that the athlete who wants to commit breach of contract by opting to play for a different club, province or union is irreplaceable, but merely that the athlete in question would not be easily replaceable.

141140 F.Supp. 364 (N.D. Ohio 1955).

${ }^{142}$ Winnipeg Rugby Football Club v Freeman 140 F.Supp. 365 (N.D. Ohio 1955) at 366; Whitehill (1981-1982) Southwestern Law Journal at p. 809.

143 Ibid.

${ }^{144}$ Brennan (1967-1968) Brooklyn Law Review 61 at p. 67.

145348 S.W. 2d 37 (Tex. Ci. App.-Dallas 1961); Whitehill (1981-1982) Southwestern Law Journal at p. 809.

${ }^{146}$ Dallas Cowboys Football Club Inc. v Harris 348 S.W. 2d 37 (Tex. Ci. App.-Dallas 1961) at 45; Whitehill (19811982) 809-810; Brennan (1967-1968) Brooklyn Law Review 61 at pp. 68-69.

${ }^{147}$ Whitehill (1981-1982) Southwestern Law Journal at p. 810.

${ }^{148}$ Uberstine and Grad (1987) Loyola Entertainment Law Journal at p. 11.

149 Ibid.

${ }^{150}$ Whitehill (1981-1982) Southwestern Law Journal at p. 810; Uberstine and Grad (1987) Loyola Entertainment Law Journal pp. 11-12.

${ }^{151}$ Philadelphia Ball Club v Lajoie 202 Pa. 210, 51 A (1902) at 210; Uberstine and Grad (1987) Loyola Entertainment Law Journal at p. 12.

${ }^{152}$ Central New York Basketball, Inc. v Barnett 19 Ohio Op. 2d 130, 181 N.E.2d 506 (1961) at 517.

${ }^{153}$ VanderVelde, $L$ (1992) “The gendered origins of the Lumley doctrine: binding men's consciences and women's Fidelity" Yale Law Journal 775 at p. 784. 